\title{
Removal of arsenic from contaminated groundwater using laterite, sand and ash: a case study in Son Dong commune, Hoai Duc district, Ha Noi
}

\author{
Loại bỏ Asen trong nước ngầm bằng cách sủ dụng đá ong, cát và tro tại xã Sơn \\ Đồng, huyện Hoài Đức, Hà Nội \\ Research article
}

Nguyen Quoc Bien, Tran Hai Nam, Nguyen Thi Hoang Ha*

Department of Geo-environment, VNU University of Science, 334 Nguyen Trai, Thanh Xuan, Ha Noi

\begin{abstract}
Arsenic (As) contaminated groundwater has been a major concern due to the negative impacts to exposed people. This research was conducted to assess and compare the removal efficiency of As from groundwater by laterite, sand, and ash. The experiment was carried out in 14 days in a household scale in Son Dong commune, Hoai Duc district, Ha Noi. Groundwater was pumped directly from a well and flowed through $20 \mathrm{~cm}$ (diameter) x $80 \mathrm{~cm}$ (length) columns. The initial As concentration in groundwater was $526 \mu \mathrm{g} / \mathrm{L}$ decreasing to an average of 189,192 and $154 \mu \mathrm{g} / \mathrm{L}$ after being filtrated using sand, ash, and laterite, respectively. Average removal efficiency of sand, ash and laterite during the experiment was 63.3, 63.9, and 70.5\%, respectively. Laterite had higher As removal efficiency may be due to higher content of goethite and kaolinite in this sorbent which resulted in better adsorption of As. The concentrations of As in the outflow water were higher than the allowable limit set by the national technical regulation on drinking water quality (QCVN 01:2009/BYT). Therefore, it requires higher volume of sorbents or additional treatment technologies for removal of As from groundwater.
\end{abstract}

Ô nhiếm asen (As) trong nuớc ngầm hiện nay là một vấn đề cấp bách đối với xã hội bởi nhũng rủi ro tiềm ẩn với sức khoẻ con nguời. Nghiên cưu được thực hiện nhằm đánh giá và so sánh khả năng hấp phu As trong nước ngầm của đá ong, cát và tro. Thí nghiệm đuợc tiến hành trong vòng 14 ngày đặt tại một hộ gia đình có nguồn nuơớc ngầm bị ô nhiễm As thuộc xã Sơn Đồng, huyện Hoài Đức, Hà Nội. Nước ngầm được bơm tù giếng và chảy qua các cột đựng vật liệu có đường kính và chiều dài lần luợt là $20 \mathrm{~cm}$ và $80 \mathrm{~cm}$. Nồng độ As ban đầu là $526 \mu \mathrm{g} / \mathrm{L}$ đã giảm xuống còn 189, 192 và $154 \mu \mathrm{g} / \mathrm{L}$ sau khi lọ bằng cát, tro và đá ong. Hiệu suất xử lý As trung bình của cát, tro và đá ong lần luợt là 63,3, 63,9 và 70,5 $\mu \mathrm{g} / \mathrm{L}$. Đá ong xử lý As tốt hơn có thể do hàm lương goethit và kaolinit cao hơn trong vật liệu hấp phu này dẫn đến khả năng hấp phu As tốt hơn. Tuy nhiên hàm luợng As trong nuơớc đầu ra vẫn chuva đạt quy chuấn cho nuớc uống (QCVN 01:2009/BYT). Do đó, cần tăng thêm luợng vật liệu hoặc kết hợp với các phuong pháp khác để xư lý As hiệu quả hơn.

Keywords: adsorption, arsenic, ash, laterite, precipitation, sand

\section{Introduction}

Arsenic (As) is a ubiquitous element found in the atmosphere, soils, rocks, natural waters and organisms. Of the various As sources in the environment, drinking water probably poses the greatest threat to human health [22]. A variety of treatment methods were developed for the removal of As from water, including coagulation [19], adsorption [5], ion exchange [2], electrocoagulation [10] and biological processes [8]. There is a variety of materials in treatment of arsenic contaminated groundwater such as bentonite [27], red mud [7], kaolinite [17], laterite [1] and raw laterite [23]. Raw laterite is an effective material 
that is environmental-friendly, affordable and available in some areas of Vietnam such as Ha Noi, Vinh Phuc, and Thai Nguyen provinces.

Vietnam is one of the countries suffering serious As contamination in groundwater. The As concentrations in the Red River and Mekong aquifers vary within $1-845 \mu \mathrm{g} / \mathrm{L}$, and $1-3050 \mu \mathrm{g} / \mathrm{L}$ (average $159 \mu \mathrm{g} / \mathrm{L}$ ), respectively [4]. The increasing demand of groundwater for domestic and drinking water has posed high risks for exposed community. Ha Noi is considered one of the most affected areas in northern Vietnam. There are eight major well fields supplying water to this city which process $500.000 \mathrm{~m}^{3}$ of water per day. However, the high As concentrations found in $48 \%$ of the tube-wells greater than $50 \mu \mathrm{g} / \mathrm{L}$ and in $20 \%$ of the tube-wells greater than $150 \mu \mathrm{g} / \mathrm{L}$ indicated that several million people consuming untreated groundwater might be at a considerable risk of chronic arsenic poisoning [3].

Hoai Duc is a district in Hanoi which suffers from As contaminated groundwater. The average As concentration in groundwater in Hoai Duc was approximately $261 \mu \mathrm{g} / \mathrm{L}$ [24]. High awareness of As problem in groundwater was observed in Son Dong commune, Hoai Duc district. Local community use both rainwater and filtered water in daily life. Some natural materials (e.g., sand, gravel, ash, pebbles) have been widely using for filtering groundwater at household scale. However, the effectiveness of these materials for As removal to meet the required regulation has not been determined. In addition, the application of natural laterite to filtrate groundwater at household scale has not been reported.

The objective of study is to assess and compare the efficiency of removing As from contaminated groundwater using laterite, sand and ash through an experiment at one household in Son Dong commune, Hoai Duc district, Ha Noi.

\section{Materials and methods}

\subsection{Field survey}

The first survey was conducted in six households in Son Dong commune, Hoai Duc district, Ha Noi in February, 2017. In these sites, sand and ash are two most common materials that local inhabitants use to filter groundwater. The outflow water after filtration is used for both drinking and domestic purposes.

A total of 12 groundwater samples at 6 households were collected. The household with highest As concentrations will be selected for further experiment.

\subsection{Experiment setup}

Laterite was collected from Thach That district of Ha Noi. Figure 1 shows the experiment which was located in a household at $21^{\circ} 02^{\prime} 50.3^{\prime \prime} \mathrm{N}$; $105^{\circ} 41^{\prime} 59.2^{\prime \prime} \mathrm{E}$ in Son Dong commune, Hoai Duc district, Ha Noi.

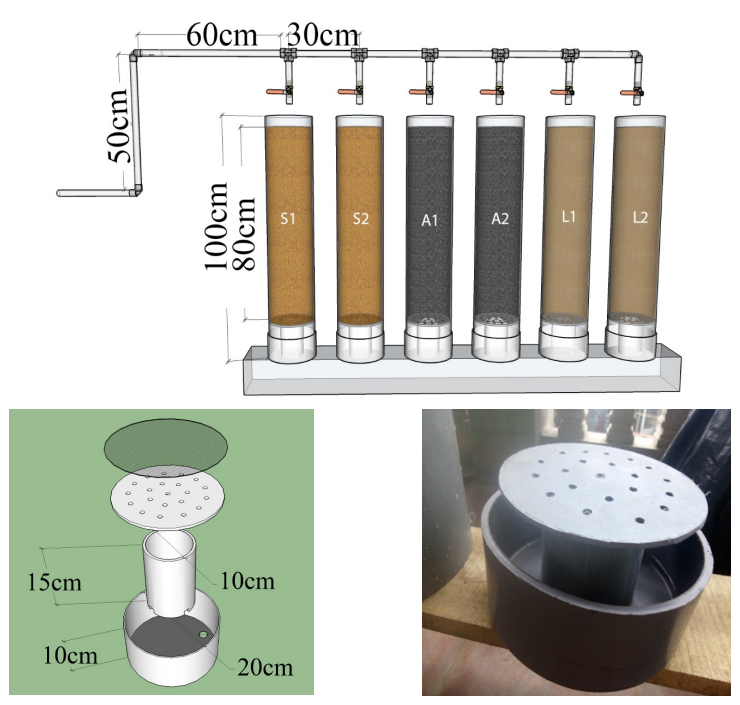

Figure 1. Experiment setup

The pilot experiment was designed three replicated with three kinds of columns containing sand, ash, laterite (Figure 1). Each material column is $80 \mathrm{~cm}$ in length and $20 \mathrm{~cm}$ in diameter to make the ratio of diameter-to-length of 1:4 [13]. The weight of sand, ash, and laterite in each column was approximately $25,2.2$, and $20 \mathrm{~kg}$, respectively. The inflow water was pumped directly from groundwater in the selected household water with a velocity of 300 $\mathrm{ml} / \mathrm{min}$. The experiment was carried out continuously in 14 days, given the constant As concentrations in the outflow water. Inflow and outflow water samples were collected after 1 hour, 3 hours, 6 hours, 1 day, 2 days, 4 days, 6 days, 8 days, 11 days, and 14 days after setting up. A total of 70 water samples were collected for determination of As concentrations.

\subsection{Sample treatment and analysis}

Water samples were first filtered through $0.45 \mu \mathrm{m}$ before As and Fe determination by Atomic Absorption Spectroscopy (AAS, 240FS, VGA77, Agilent) at the VNU Key Laboratory of Geo-environment and Climate change Response.

Samples of laterite, sand and ash were dried using the NIIVE OVER KD200 oven at the temperature of $80-$ $105^{\circ} \mathrm{C}$ until the sample weight was constant. After the samples were dried, samples were crushed into fine powder using the MRC laboratory Equipment Manufac Urer. Mineral compositions of the material samples were determined using the X-ray Diffraction (XRD - Siemens D5000) at VNU University of Science.

\subsection{As removal efficiency calculation}

The As removal efficiency (\%) of different materials is calculated by the equation:

$$
\%=\frac{C_{o}-C_{e}}{C_{o}} \times 100 \%
$$

Where: $\mathrm{C}_{\mathrm{o}}$ : Initial As concentration $(\mu \mathrm{g} / \mathrm{L})$

$\mathrm{C}_{\mathrm{e}}$ : As concentration at equilibrium state $(\mu \mathrm{g} / \mathrm{L})$ 


\section{Results and discussions}

\subsection{Mineral compositions of materials}

The results of this study demonstrated that the main minerals of sand and ash were quartz with the proportions of $90 \%$ and $8.2 \%$, respectively. The main components of laterite were goethite $(42 \%)$ and kaolinite $(40 \%)$. Other minor components of laterite were quartz $(9 \%)$, hemantite (3\%), titanite, azurite, magnetite, pyrite.

\subsection{As concentrations $(\mu \mathrm{g} / \mathrm{L})$ and $\mathrm{Fe} / \mathrm{As}$ ratios in study sites}

The initial As concentrations measured in six study sites from HD1 to HD6, in Son Dong commune, Hoai Duc district varied from $82 \mu \mathrm{g} / \mathrm{L}$ in HD1 to $575 \mu \mathrm{g} / \mathrm{L}$ in HD4 (Figure 2). The As concentrations of HD2, HD3, HD5 and HD6 were 290, 302, 286 and $328 \mu \mathrm{g} / \mathrm{L}$, respectively (Figure 2). The average As concentration in 6 sites was 311 $\mu \mathrm{g} / \mathrm{L}$. The site HD4 was selected for further experiment due to the highest concentration of As among the 6 investigating sites. At low horizontal hydraulic gradients and under reducing conditions, As was released in groundwater by microbial activity, causing widespread contamination in the low-lying deltaic and floodplain areas [21]. The weathering of As-bearing minerals released this element into water flows. Under the influence of tectonic, geodynamic, those As-bearing materials were transported from the high-altitude areas to low-altitude areas. The relationship is non-linear between As content in groundwater and surface elevation of study sites. This indicated that the surface topography is inversely related with As concentration in the study area [9].

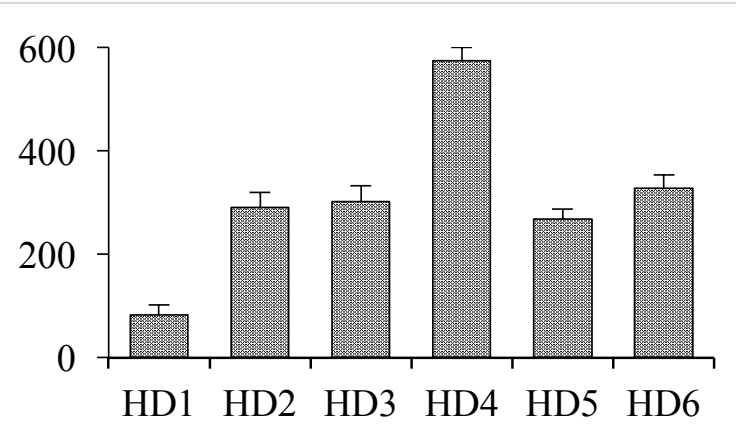

Figure 2. Initial As concentrations in study sites

Table 1. Fe/As ratios in sampling sites

Sampling sites

$\mathrm{Fe} / \mathrm{As}$ ratio

$\begin{array}{ll}\text { HD1 } & 51 \\ \text { HD2 } & 58 \\ \text { HD3 } & 49 \\ \text { HD4 } & 21 \\ \text { HD5 } & 45 \\ \text { HD6 } & 57\end{array}$

The proportion of dissolved iron $(\mathrm{Fe})$ and As present in groundwater is a suitable parameter for estimating the As removal potential. The concentration of dissolved $\mathrm{Fe}$ is a key parameter for As removal from groundwater [4]. Table 2 showed that Fe/As ratios in groundwater collected at six study sites from HD1 to HD6 were 51, 58, 49, 21, 45 and 57, respectively. The different concentrations of Fe may be one of the reasons causing the change of As concentrations in locations because As removal is directly related to the concentration of $\mathrm{Fe}$ added to the system. The high content of $\mathrm{Fe}$ available in groundwater may combine with As via co-precipitation which results in the removal of As. For example, to reduce the As concentration from $100 \mu \mathrm{g} / \mathrm{L}$ to reach the value less than $5 \mu \mathrm{g} / \mathrm{L}$, it requires the $\mathrm{Fe} / \mathrm{As}$ ratio as 40 [18]. Another study indicated that the $\mathrm{Fe} / \mathrm{As}$ ratio of 50 or more was needed to reduce As concentrations to levels below $50 \mu \mathrm{g} / \mathrm{L}$. To reach the WHO drinking water guideline of $10 \mu \mathrm{g} \mathrm{As} / \mathrm{L}, \mathrm{Fe} / \mathrm{As}$ ratios of $>250$ were required [4]. Fe/As ratio measured in the experiment site HD4 - the selected experiment site was 21 which may result in high concentrations of As in this area. Low $\mathrm{Fe} / \mathrm{As}$ ratio in this site also highlights the need for using Fe-rich materials for treatment of As contaminated water to regulated level.

\subsection{Removal of As by laterite, sand, and ash}

\subsection{1. pH}

Figure 3 showed $\mathrm{pH}$ values of the inflow and outflow water samples. The $\mathrm{pH}$ values of water passing through laterite columns slightly decreased while those of sand and ash increased during the experiment. However, the $\mathrm{pH}$ values always remains within the allowance limit of pH in drinking water (QCVN01:2009/BYT).

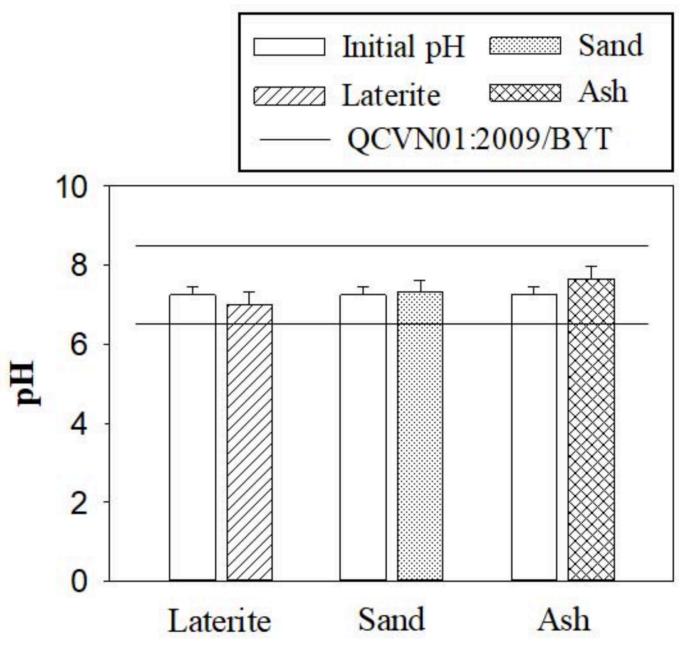

Figure 3. pH values in inflow and outflow water samples

\subsubsection{Removal of As in groundwater by laterite, sand, and ash}

Average As concentration in inflow water was $524 \mu \mathrm{g} / \mathrm{L}$ which decreased to 73,80 , and $82 \mu \mathrm{g} / \mathrm{L}$ by laterite, sand, and ash, respectively in one hour of treatment (Figure 4). After 14 days of the experiment, the average As concentrations decreased to 189,192 and $154 \mu \mathrm{g} / \mathrm{L}$ by sand, ash and laterite, respectively. The removal of As by laterite, sand, and ash was due to the oxidation of iron and arsenite and precipitation of iron(III) arsenate [12] as follow:

$\mathrm{Fe}^{3+}+\mathrm{HAsO}_{4}{ }^{2-} \rightarrow \mathrm{FeAsO}_{4}$ (precipitation) $+\mathrm{H}^{+}$ 
Therefore, laterite, sand, and ash using for filtration of groundwater may provide a surface network to mechanically keep the precipitation of $\mathrm{As}$ and $\mathrm{Fe}$ compounds. $\mathrm{Fe} / \mathrm{As}$ ratio in groundwater is thus the important factor affecting the As removal capacity [4].

The results of this study showed the significant decrease of As concentrations by laterite in comparison with those by sand and ash $(p<0.05)$. However, no significant difference of As concentrations in outflow water between using sand and ash was obtained. Higher content of goethite $(42 \%)$ and kaolinite (40\%) in laterite may cause the adsorption of As to these minerals and thus resulting in better removal of As from contaminated groundwater [23][14].

Many studies showed that higher As removal efficiencies can be generally achieved with increased Fe concentrations. As adsorbed onto ferric hydroxide was investigated for arsenite and arsenate in a $\mathrm{pH}$ range of 4-9 at varying Fe to As ratios. The extent of arsenite adsorption at $\mathrm{pH} 4$ and 7 demonstrated strongly dependent on total arsenite concentration, and increased adsorption was observed with increasing $\mathrm{Fe} / \mathrm{As}$ ratios [26]. It was also observed from this study that As concentrations in outflow water were higher than the limit set by national technical regulation on drinking water quality (QCVN 01:2009/BYT) [19]. This fact highlights the need to add more sorbents, to use modified materials for better adsorption, or to combine with other technologies in order to meet the regulation of As in drinking water. In addition, the sand columns started to stuck after 2 days of experiments, possibly due to the precipitation filling the porosity of these sand columns.

The highest As removal efficiency was obtained on the first day of the experiment. From the second to the end of the experiment, As removal efficiencies by the 3 materials were almost constant. The average As removal efficiency of laterite, sand, and ash during 14 days of the experiment was 70.5, 63.9, and 63.3\%, respectively (Figure. 5). As removal by laterite was significantly higher than that by sand and ash $(p<0.05)$. The results of this study also demonstrated lower removal efficiency of As than those reported in the previous studies (Table 2). The differences were possibly due to the differences in characteristics of sorbents, initial concentrations of As in groundwater, composition of groundwater and experimental designs.

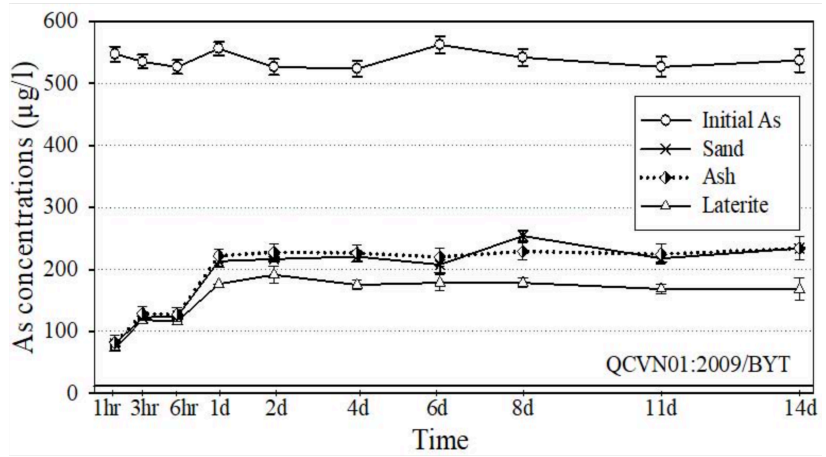

Figure 4. As concentrations $(\mu \mathrm{g} / \mathrm{L})$ in inflow and outflow waters

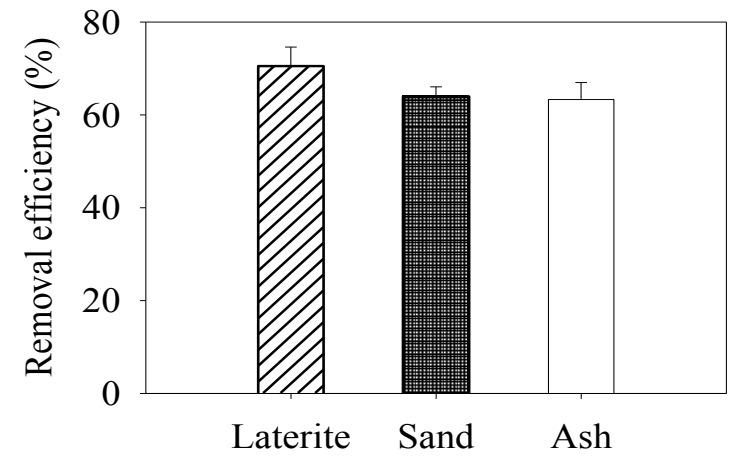

Figure 5. Average As removal efficiency of materials during 14 days of the experiment

Table 2. Comparison of different As sorbents with similar column filter (Note: - No data)

\begin{tabular}{|c|c|c|c|c|c|c|}
\hline Sorbents & $\begin{array}{c}\text { As initial } \\
\text { concentration } \\
(\mu \mathrm{g} / \mathrm{L})\end{array}$ & $\begin{array}{l}\text { Column } \\
\text { diameter } \\
(\mathrm{cm})\end{array}$ & Flow rate & $\begin{array}{c}\text { As removal } \\
\text { efficiency } \\
(\%)\end{array}$ & $\begin{array}{c}\text { As outflow } \\
\text { concentration } \\
(\mu \mathrm{g} / \mathrm{L})\end{array}$ & Reference \\
\hline Laterite & 526 & $20 \times 80$ & $300 \mathrm{ml} / \mathrm{min}$ & 70.5 & 154 & This study \\
\hline Laterite soil & 330 & $2 \times 10$ & $7.75 \mathrm{ml} / \mathrm{min}$ & 98 & 10 & {$[15]$} \\
\hline Manganese greensand & 100 & - & $1.5 \mathrm{l} / \mathrm{min}$ & 81 & - & [25] \\
\hline $\begin{array}{l}\text { Iron oxide-coated cement } \\
\text { (IOCC) }\end{array}$ & 2,000 & $\begin{array}{l}2 \times 10 ; 2 \times \\
20 ; 2 \times 30\end{array}$ & $8.5 \mathrm{ml} / \mathrm{min}$ & - & 10 & [11] \\
\hline Siderite-hematite & 500 & $0.3 \times 15$ & $0.51 \mathrm{ml} / \mathrm{min}$ & 99 & $<10$ & [6] \\
\hline Calcined bauxite ore & 2,000 & $6 \times 30$ & $200 \mathrm{ml} / \mathrm{h}$ & - & $<10$ & [16] \\
\hline
\end{tabular}

\section{Conclusions}

The initial As concentration is $526 \mu \mathrm{g} / \mathrm{L}$ decreased to an average of 189,192 and $154 \mu \mathrm{g} / \mathrm{L}$ by sand, ash and laterite during 14 days of the experiment. As removal efficiency of sand, ash and laterite was 63.3, 63.9 and $70.5 \%$, respectively. As removal from groundwater by laterite, ash, and sand may be due to precipitation. Higher As removal efficiency of laterite than ash and sand was possibly due to higher content of goethite and kaolinite in laterite. The materials should be modified or combined

with other technologies for treatment of As in groundwater to meet the regulation for drinking water (QCVN01:2009/BYT).

\section{References}

[1] Abhijit M., Sunado D., Jayant K.B. and Sirshendu D. (2007) Adsorption of arsenite using natural laterite as adsorbent, Separation and Purification Technology, 55: 350-359. 
[2] Barakat M.A. and Ismat Shah S. (2013) Utilization of anion exchange resin Spectra/Gel for separation of arsenic from water, Arabian Journal of Chemistry, 6(3): 307-311.

[3] Berg M., Con T.H., Chuyen N.T., Hung P.V, Schertenleib R. and Giger W. (2001) Arsenic Contamination of Groundwater and Drinking Water in Vietnam: A Human Health Threat, Environmental Science and Technology, 35(13): 2621-2626.

[4] Berg M., Stengel C., Trang P.T.K., Viet P.H., Sampson M.L., Leng M., Samreth S. and Fredericks D. (2006) Magnitude of arsenic pollution in the Mekong and Red River Deltas-Cambodia and Vietnam, Science of Total Environment, 372(2-3): 413-425.

[5] Feng Q., Zhanga F.Z., Chena Y., Chena L., Zhang Z. and Chen C. (2013) Adsorption and desorption characteristics of arsenic on soils: kinetics, equilibrium, and effect of $\mathrm{Fe}(\mathrm{OH}) 2$ colloid, $\mathrm{H} 2 \mathrm{SiO} 3$ colloid and phosphate, Procedia Environmental Sciences, 18: 26-36.

[6] Guo H., Stuben D., Berner Z. and Kramar U. (2007) Adsorption of arsenic species from water using activated siderite-hematite column filters, Journal of Hazardous Materials, 151: 628-635.

[7] Hülya G, Christian T., David M. and Olaf S. (2003) Adsorption of arsenate from water using neutralized red mud, Journal of Colloid and Interface Science, 24(3): 267-272.

[8] Katsonyannis I.A. and Zhouboulis A.I. (2004) Application of biological processes for the removal of arsenic from groundwaters, Wat. Res., 38(1): 17-26.

[9] Khan T.A., Rahman A., Ali I., Khan J. and Alam S.D. (2016) Assessing spatial variations of groundwater arsenic with surface elevation, slope and water-table using geospatial techniques in Ballia district, India, Modeling Earth Systems and Environment, 2: 83 .

[10] Kumar R., Chaudhary P., Khilar S. and Mahajan K.C. (2004) Removal of arsenic from water by electro coagulation, Chemosphere, 55(9): 1245-1252.

[11] Kundu S. and Gupta A.K. (2005) Analysis and modeling of fixed bed column operations on As(V) removal by adsorption onto iron oxide-coated cement (IOCC), Journal of Colloid and Interface Science, 290:52-60.

[12] Lenoble V., Laclautre C., Deluchat V., Serpaud B. and Bollinger J.C. (2005) Arsenic removal by adsorption on iron (III) phosphate, Journal of Hazardous Materials, 123(1-3): 262-268.

[13] Lewis J., Sjöstrom J. (2010) Optimizing the experimental design of soil columns in saturated and unsaturated transport experiments, Journal of Contaminant Hydrology, 115(1-4): 1-13.

[14] Maiti A., Sharma H., Basu J.K. and De S. (2009) Modeling of arsenic adsorption kinetics of synthetic and contaminated groundwater on natural laterite,
Journal of Hazardous Materials, 172(2-3): 928-934.

[15] Maji S.K., Pal A. and Pal T. (2007) Arsenic removal from real-life groundwater by adsorption on laterite soil, Journal of Hazardous Materials, 151: 811-820.

[16] Mohapatra D., Mishra D. and Park K.H. (2007) A laboratory scale study on arsenic(V) removal from aqueous medium using calcined bauxite ore, Journal of Environmental Sciences, 20: 683-689.

[17] Mohapatra D., Mishra D., Chaudhury H.R. and Das R.P. (2007) Arsenic(V) adsorption mechanism using kaolinite, montmorillonite and illite from aqueous medium, Journal of Environmental Science and Health, 42(4): 463-469.

[18] Pokhrel D., Viraraghavan T. (2009) Biological filtration for removal of arsenic from drinking water, Journal of Environmental Management, 90: 19561961.

[19] QCVN01:2009/BYT, National technical regulation on drinking water quality, Vietnam Ministry of Health, 9 pages.

[20] Sancha A.M. (2006) Review of Coagulation Technology for Removal of Arsenic: Case of Chile, Journal of Health, Population and Nutrient, 24(3): 267272.

[21] Shamsudduha M., Uddin A., Saunders J.A. and Lee M.K. (2008) Quaternary stratigraphy, sediment characteristics and geochemistry of arseniccontaminated alluvial aquifers in the GangesBrahmaputra floodplain in central Bangladesh, Journal of Contamination Hydrology, 99(1-4): 112-136.

[22] Smedley P.L. and Kinniburgh D.G. (2002) A review of source, behavior and distribution of arsenic in natural waters, Applied Geochemistry, 17: 517-568.

[23] Thao N.H.P., Ha N.T.H., Thuy P.T., Khai N.M. and Nga T.T.H. (2016) The sorption ability of Tam Duong and Thach That laterite in the treatment of heavy metals and arsenic, VNU Journal of Science, Earth Sciences 32(1S): 321-326.

[24] Trang P.T.K., Lan V.T.M. and Viet P.H. (2012) Human exposure to arsenic and manganese in groundwater in the Red River Delta, Vietnam, In the book: Understanding the geological and medical interface of arsenic, Editor: Jack C.N., Noller B.N., Naidu R., Bundschuh J., Bhattacharya P., 115-128.

[25] Viraraghavan T., Subramanian K.S. and Aruldoss J.A. (1999) Arsenic in drinking water - Problems and solutions, Water Sci Technol, 40(2): 69-76.

[26] Wilkie J.A., Hering J.G. (1995) Adsorption of arsenic onto hydrous ferric oxide: Effects of adsorbate/adsorbent ratios and co-occurring solutes, Colloids and Surfaces A: Physicochemical and Engineering Aspects, 107: 97-110.

[27] Zahra N., Sheikh S.T., Mahmood A. and Javed K. (2009) Removal of Arsenic From Wastewater Using Bentonite, Bangladesh, Journal of Scientific and Industrial Research, 44(1): 81-86. 